\title{
Geographic distribution of Pristimantis vinhai (Bokermann, 1975) (Anura, Craugastoridae: Ceuthomantinae) in the Brazilian Atlantic Forest
}

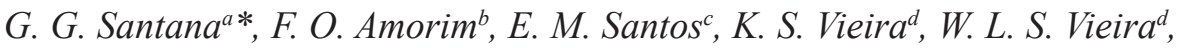 \\ P. F. G. P. Montenegro and R. R. N. Alves
}

\begin{abstract}
aPrograma de Pós-graduação em Ecologia e Conservação - PPGEC, Departamento de Biologia, Centro de Ciências Biológicas e da Saúde - CCBS, Universidade Estadual da Paraíba - UEPB, Rua Baraúnas, 351, Bairro Universitário, CEP 58429-500, Campina Grande, PB, Brazil
\end{abstract}

'Laboratório de Ecofisiologia e Comportamento Animal - LECA, Departamento de Biologia, Universidade Federal Rural de Pernambuco - UFRPE, Rua Dom Manoel de Medeiros, s/n, Dois Irmãos, CEP 52171-900, Recife, PE, Brazil

`Área de Ensino, Departamento de Biologia, Universidade Federal Rural de Pernambuco - UFRPE,

Rua Dom Manoel de Medeiros, s/n, Dois Irmãos, CEP 52171-900, Recife, PE, Brazil

${ }^{\mathrm{d}}$ Laboratório de Ecofisiologia Animal, Departamento de Sistemática e Ecologia - DSE,

Centro de Ciências Exatas e da Natureza - CCEN, Universidade Federal da Paraíba - UFPB,

Cidade Universitária, s/n, Castelo Branco, CEP 58051-900, João Pessoa, PB, Brazil

eDepartamento de Biologia, Centro de Ciências Biológicas e da Saúde - CCBS,

Universidade Estadual da Paraíba - UEPB, Rua Baraúnas, 351, Bairro Universitário, CEP 58429-500, Campina Grande, PB, Brazil

*e-mail: gindomar@yahoo.com.br

Received: November 22, 2014 - Accepted: March 4, 2015 - Distributed: May 31, 2016

(With 2 figures)

Only three species of Pristimantis have been recorded in Atlantic Forest remnant areas in Northeast Brazil: P. paulodutrai (Bokermann, 1975), with records from Alagoas State south to Bahia State; P. ramagii (Boulenger, 1888), distributed from Paraiba State to northern Bahia; and P. vinhai (Bokermann, 1975 “1974”), with records only for southern Bahia State and eastern Sergipe State (Silvano and Pimenta, 2003; Juncá, 2006; Morato et al., 2011; Frost, 2014).

The present work presents three new records for the occurrence of P. vinhai (Bokermann, 1975 “1974”) in the Atlantic Forest in Northeast Brazil (Figures 1 and 2a, b). A specimen was collected in the Mata do Buraquinho Permanent Preservation Area (708'42"S, 3451'54"W) in the municipality of João Pessoa, Paraiba State (July 5, 2005), and seven additional specimens were collected in Mata do Açude Cafundó $\left(07^{\circ} 10^{\prime} \mathrm{S}, 35^{\circ} 05^{\prime} \mathrm{W}\right)$ in the municipality of Cruz do Espirito Santo, located approximately $20 \mathrm{~km}$ west of the Mata do Buraquinho site (August 22, 2004). One additional specimen was found in the Mata da Usina

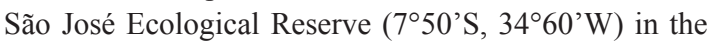
municipality of Igarassu, Pernambuco State (May 6, 2011) (72.8 km from Mata do Açude Cafundó and $77.2 \mathrm{~km}$ from Mata do Buraquinho). The occurrence of populations of P. vinhai in the Atlantic Forest of Pernambuco and Paraiba States extends its geographic distribution, respectively 375 and $429 \mathrm{~km}$ north of the last occurrence area, namely Refúgio de Vida Silvestre Mata do Junco, in the municipality of Capela, in western Sergipe State (Morato et al., 2011). It is probable that populations of $P$. vinhai will be found in forest fragments in Alagoas State (located between Sergipe and Pernambuco).

\section{Diagnosis}

The specimens of $P$. vinhai were diagnosed by the combination of the following characters: small size (adult male $(\mathrm{n}=1)$ - SVL: $17.2 \mathrm{~mm})$; adult females $(\mathrm{n}=5)$ - SVL $26.6 \pm 1.8 \mathrm{~mm}$; range: $23.7-28.5 \mathrm{~mm}$ ); presence of small tubercles in upper eyelids; relative length of fingers of the forelimbs: I $\approx$ II $<$ III $>$ IV; adhesive discs of fingers I and II slightly wider than its phalanges; III and IV fingers with wider adhesive discs than its phalanges; well developed subarticular tubercles; Inner carpal tubercle well developed, ovoid. Outer carpal tubercle composed by two or three smaller tubercles. Toes of the hindlimbs long and thin with well developed adhesive discs, except that of toe I. The relative size of toes: $\mathrm{I}<$ II $<$ III $\approx \mathrm{V}<$ IV. Inner metatarsal tubercle large, prominent, ovoid. Outer metatarsal tubercle small. Mid-dorsal stripe beige colored extending from snout to cloacal region being wider at anterior portion of the snout. In some specimens, the beige medium-dorsal stripe can be absent. A red spot on the inner and outer sides of the thighs can be present or absent.

All specimens examined have been deposited in the Herpetology Collection at the Department of Systematics and Ecology at the Federal University of Paraíba (UFPB) in João Pessoa and in the Herpetology Collection of the Federal Rural University of Pernambuco, Serra Talhada Campus (UFRPE). Material examined: Mata do Açude Cafundó (municipality of Cruz do Espírito Santo, Paraiba State): 


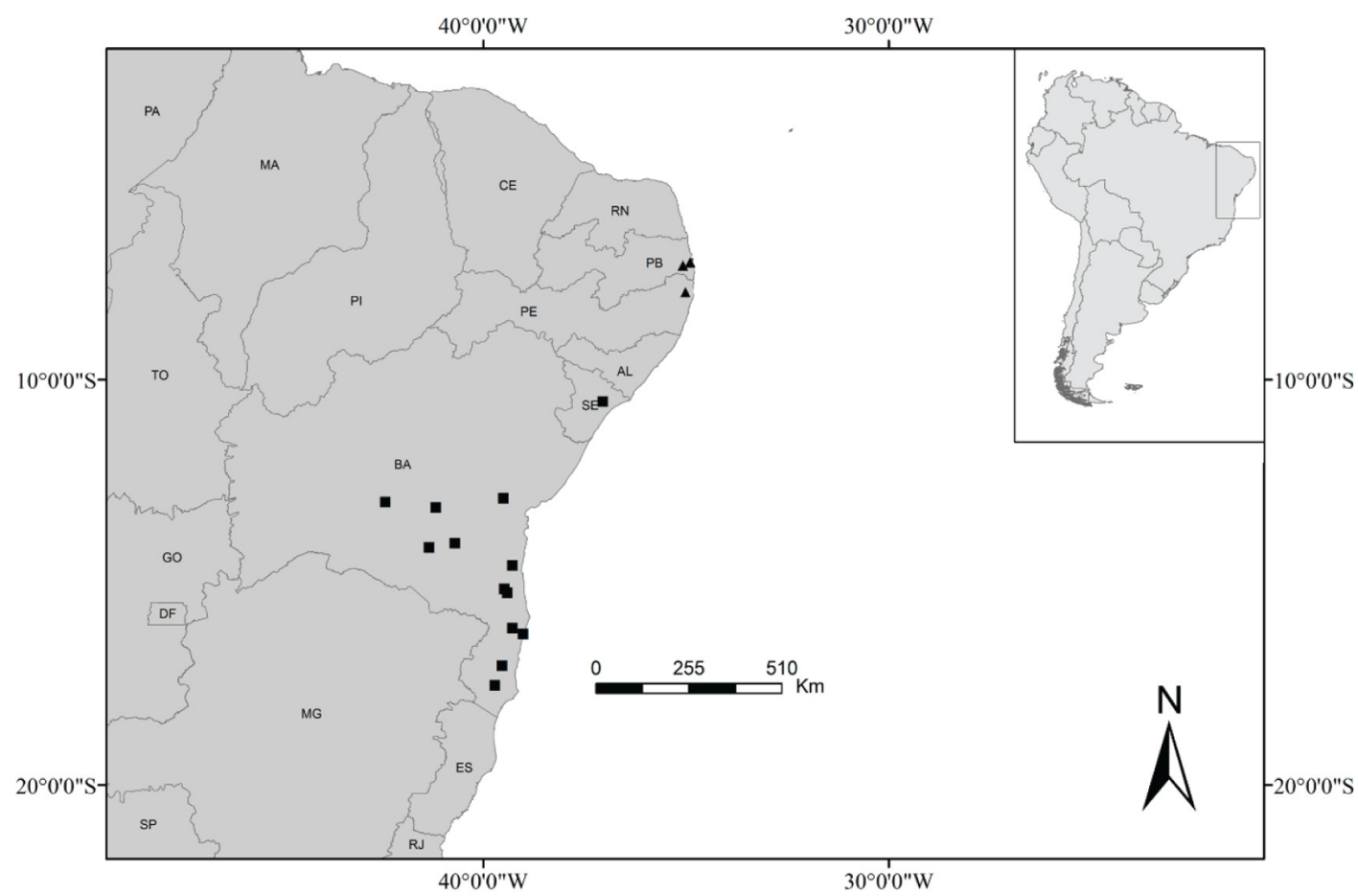

Figure 1. Map of the distribution of populations of Pristimantis vinhai in remnants of the Atlantic Forest in Northeast Brazil. The new localities are indicated by triangles and squares for earlier ones.
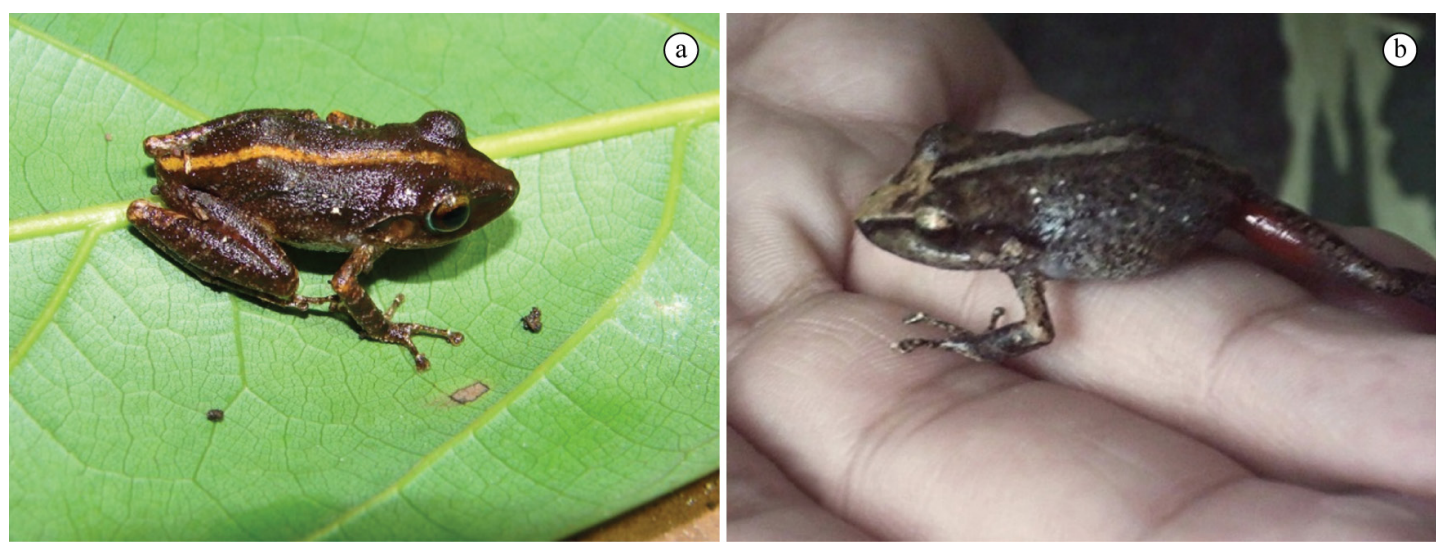

Figure 2. Specimens of Pristimantis vinhai from the (a) Mata do Açude Cafundó (municipality of Cruz do Espirito Santo, Paraiba State, Brazil) and (b) Ecological Reserve of Usina São José (municipality of Igarassu, Pernambuco State, Brazil). Photographs: (a) Washington L. S. Vieira, and (b) Fabiana O. Amorim.

UFPB 4917-4923; Mata do Buraquinho (municipality of João Pessoa, Paraiba State): UFPB 4924; Reserva Ecológica da Usina São José (municipality of Igarassu, Permanbuco State): CHUFRPE-905; and Estação Ecológica do Pau Brasil/CEPLAC (municipality of Porto Seguro, Bahia State): UFPB 4878-4916.

\section{Acknowledgements}

The authors would like to thank CAPES for the postdoctoral grant (Programa Nacional de Pós-Doutorado - PNPD/ Programa de Pós-graduação em Ecologia e Conservação
-PPGEC/UEPB) awarded to Gindomar Gomes Santana, Companhia Usina São João for support, and IBAMA/RAN for authorization to undertake these collections (Licença: 133/06 - IBAMA/RAN).

\section{References}

BOKERMANN, W.C.A., 1975. Três espécies novas de Eleutherodactylus do sudeste da Bahia, Brasil. Brazilian Journal of Biology = Revista Brasileira de Biologia, vol. 34, no. 1, pp. 11-18.

FROST, D.R., 2014 [viewed 20 September 2014]. Amphibian species of the World: an online reference. Version 6.0 [online]. 
New York: American Museum of Natural History. Available from: http://research.amnh.org/herpetology/amphibia/index.html

JUNCÁ, F.A., 2006 [viewed 20 September 2014]. Diversidade e uso de habitat por anfíbios anuros em duas localidades de Floresta Atlântica, no norte do estado da Bahia. Biota Neotropica, vol. 6, no. 2. Available from: http://www.biotaneotropica.org.br/v6n2/ pt/abstract?inventory+bn03006022006

MORATO, S.A.A., LIMA, A.M.X., STAUT, D.C.P., FARIA, R.G., SOUZA-ALVES, J.P., GOUVEIA, S.F. and CAVILHA,
M.R., 2011. Amphibians and reptiles of the Refúgio de Vida Silvestre Mata do Junco, municipality of Capela, State of Sergipe, Northeastern Brazil. Check List, vol. 7, no. 6, pp. 756-762. http:// dx.doi.org/10.15560/11015.

SILVANO, D.L. and PIMENTA, B.V.S., 2003. Diversidade de anfíbios na Floresta Atlântica do Sul da Bahia. In: P.E. PRADO, E.C. LANDAU, R.T. MOURA, L.P.S. PINTO, G.A.B. FONSECA and K. ALGER, orgs. Corredor de Biodiversidade na Floresta Atlântica do Sul da Bahia. Ilhéus/Belo Horizonte/Campinas: IESB/CI/CABS/UFMG/UNICAMP. CD-ROM. 